\title{
Discriminating unifloral honey from a dioecious mass flowering tree of Brazilian seasonally dry tropical forest through pollen spectra: consequences of honeybee preference for staminate flowers
}

\author{
Paula CALAÇA ${ }^{1,2}$, Clemens Schlindwein ${ }^{1}$, Esther Margarida Alves Ferreira Bastos ${ }^{2}$ \\ ${ }^{1}$ Departamento de Botânica, Universidade Federal de Minas Gerais, Avenida Antônio Carlos, 6627, Belo Horizonte, \\ Pampulha 31270-901, Brazil \\ ${ }^{2}$ Diretoria de Pesquisa e Desenvolvimento, Fundação Ezequiel Dias, Rua Conde Pereira Carneiro 80, Belo Horizonte, \\ Gameleira 30510-010, Brazil
}

Received 19 February 2018 - Revised 21 June 2018 - Accepted 23 July 2018

\begin{abstract}
Myracrodruon urundeuva ("aroeira") is a dioecious tree of the seasonally dry tropical forest (SDTF) of Brazil and source of a unique unifloral honey. To discriminate this honey by its pollen spectra, we compared melissopalynological analysis of reference honey samples with those of other samples collected in the SDTF belt. Reference honeys had on average $99 \%$ of aroeira pollen, while the other honey samples averaged $84 \%$ of this pollen. We used the receiver operating characteristic (ROC) curve, applied here for the first time in honey analysis, for determining the cut-off value of at least 93\% of Myracrodruon pollen in a sample for classifying unifloral aroeira honey. The over-representation of aroeira pollen in this honey reflects that honeybees visited ten times as many staminate flowers as pistillate flowers. We conclude that unifloral aroeira honey has uniform pollen spectra, as a byproduct of the preference of honeybees for staminate flowers.
\end{abstract}

Myracrodruon urundeuva / receivers operating characteristic (ROC) curve / melissopalynology / Apis mellifera

\section{INTRODUCTION}

Pollen analysis of honey provides a microscopic fingerprint of the environment from which the honey came and can serve as criteria for quality and origin control (Louveaux et al. 1978; Barth 1989; Barth 2004; Von Der Ohe et al. 2004; Marquele-Oliveira et al. 2017). Mixed with nectar, pollen grains enter honey in varying quantities depending on flower morphology, flower size, and pollen production per anther (Todd and Vansell 1942; Maurizio and Hodges 1951;

Corresponding author: C. Schlindwein, schlindw@gmail.com

Handling editor: Klaus Hartfelder
Faegri et al. 1989). Moreover, small pollen grains adhering to the body surface of honeybees more frequently contaminate honey than large ones (Maurizio and Hodges 1951; Bryant Jr and Jones 2001). Pollen from flowers with easily accessible anthers and numerous small pollen grains is generally over-represented in honey, such as Eucalyptus and Castanea (Louveaux et al. 1978; Von Der Ohe et al. 2004; Nedic et al. 2013). In contrast, those with large pollen grains or with nectar flowers that produce small quantities of pollen and deposit pollen on specific body parts of bees may be underrepresented, such as Citrus and Lamiaceae species (Louveaux et al. 1978; Von Der Ohe et al. 2004; Westerkamp and Claßen-Bockhoff 2007; Nedic et al. 2013).

Floral honey produced mainly from one plant species is referred to as unifloral. Unifloral honey 
has a pollen spectrum where one species is predominant; that is, it accounts for more than $45 \%$ of the pollen grains in the honey (Maurizio and Hodges 1951; Louveaux et al. 1978; Anklam 1998; Von Der Ohe et al. 2004). Unifloral honeys have, in general, greater commercial value than heterofloral honeys because they possess specific physicochemical and organoleptic characteristics, and specific tastes and flavors (Oddo et al. 1995; Anklam 1998; Terrab et al. 2014; Makhloufi et al. 2015; Fagúndez 2016; Kadri et al. 2016; Tette et al. 2017).

Unifloral honeys originate in environments that experience mass flowering of a single melliferous plant species. This can occur in non-natural environments such as monoculture plantations of rapeseed (Brassica napus L., Brassicaceae), sunflowers (Helianthus annuus L., Asteraceae), lavender (Lavandula angustifolia Mill., Lamiaceae), orange (Citrus spp., Rutaceae), eucalypt (Eucalyptus spp., Myrtaceae), among others (Louveaux and Vergeron 1964; Louveaux et al. 1978; Goplen 1980; Moar 1985; Oddo et al. 1995; Bryant Jr and Jones 2001; Nedic et al. 2013; Consonni and Cagliani 2015; Makhloufi et al. 2015; Fagúndez 2016; Kadri et al. 2016;).

Unifloral honeys from natural or near-natural plant cover are rare and can only be obtained in homogenous vegetation types with low plant diversity or where mass flowering species temporarily dominate the floral resources under highly seasonal climatic conditions. The seasonally dry tropical forest (SDTF) of Brazil experiences such high seasonality with well-defined dry and rainy seasons (Santos et al. 2012). The majority of species flower in the rainy season, while during the severe dry season woody plants shed their leaves, the herbaceous plant layer disappears, and only a few trees set blossoms (Santos et al. 2012).

Myracrodruon urundeuva Freire Alemao (Anacardiaceae), commonly referred to as "aroeira" in Brazil, is a common deciduous tree in the SDTF, and which intensely blooms during the dry season (Santin and Leitão 1991). Bees are cited as the main pollinators of the species (Kiill et al. 2010), and beekeepers know this species as an excellent nectar and pollen source for honeybees and stingless bees in the region. The results of the first pollen analysis of honey collected in the Brazilian SDTF during the dry season showed an extraordinary high content of aroeira pollen (Bastos et al. 2016). Differing from most other mass flowering food resources for honeybees, M. urundeuva is dioecious (Santin and Leitão 1991) and both pistillate and staminate flowers produce nectar. Thus, the unisexual flowers have different displays and resources and may have different attractiveness to bees.

Aiming to know if honeybees have preference to flowers of one of the genders and to discriminate unifloral aroeira honey by pollen analysis, we determined the frequency of visits to staminate and pistillate flowers and established reference honey samples produced in monitored experimental hives in a preserved SDTF fragment. We compared the monitored samples with numerous other honey samples produced within the Brazilian SDTF belt during the flowering period of aroeira. To establish a cut-off value to discriminate aroeira honey by its pollen spectra, we used the receiver operating characteristic (ROC) curves as tool. So, we asked: How does aroeira pollen content differ among the samples? Do honeybees visit staminate and pistillate flowers with the same frequency, and do plants of both genders make the same contribution to honey?

\section{MATERIAL AND METHODS}

\subsection{Study species and sites}

Myracrodruon urundeuva is native to the Gran Chaco domain in Paraguay, Argentina, and Bolivia, while in Brazil, the species occurs in the Caatinga, Cerrado, Atlantic Forest, and the belt of seasonally dry tropical forest, where it is particularly abundant (Santin and Leitão 1991; Caetano et al. 2008; Santos et al. 2012). This vegetation neighbors the Caatinga domain to the north and northeast, with transition to the Cerrado to the south and west (Brandão 1994; Santos et al. 2012). According to Pennington et al. (2009), SDTF is comprised of tall forest on moister sites, to scrub rich in succulent plants on the driest sites. Water availability is erratic and, in general, substrates are mineral rich (Pennington et al. 2009). The vegetation is dominated by trees, most of which are deciduous during the dry season (Santos et al. 2012). The dry period, from April to September, is pronounced. The vegetation at the studied site is composed of 
widespread characteristic SDTF species, which include Anadenanthera peregrina (L.) Speg. (Fabaceae), Cordia trichotoma (Vell.) Arráb. ex Steud. (Boraginaceae), Chaetocalyx acutifolia (Vogel) Benth. (Fabaceae), Ceiba speciosa (A. St.-Hil.) Ravenna (Malvaceae), Commiphora leptophloeos (Mart.) J.B. Gillett (Burseraceae), Cnidoscolus pubescens Pohl (Euphorbiaceae), Neoglaziovia variegara (Arruda) $\mathrm{Mez}$ (Bromeliaceae), Schinopsis brasiliensis Engl., Spondias tuberosa Engl. (Anacardiaceae), Triplaris gardneriana Wedd. (Polygonaceae). The common name "aroeira" is also used for other tree species of Anacardiaceae in Brazil, including other species of the genus Myracrodruon, and species from Schinus and Astronium. Individuals of M. urundeuva can reach $25 \mathrm{~m}$ in height, and several studies have reported that it is one of the most frequent and widespread species in the region of the SDTF, where the present study was undertaken (Andrade-Lima 1981; Prado and Gibbs 1993; Santos et al. 2007; Caetano et al. 2008; Santos et al. 2012; Calvo-Rodriguez et al. 2017). Myracrodruon urundeuva is widely used in popular therapeutic treatments (Monteiro et al. 2012), due to the high concentration of secondary metabolites present in vegetative parts (Viana et al. 1995; Queiroz et al. 2002).

\subsection{Honey samples}

The study analyzed 190 honey samples, which were divided into two groups. One group, the reference group, is composed of 10 samples collected in a monitored SDTF site, where the abovecited plant species are common. The second group, the evaluation group, is composed of 180 honey samples from numerous locations within the SDTF belt (see below).

Reference group The ten samples that compose the reference group came from a reference site $\left(43^{\circ}\right.$ $31^{\prime} 06^{\prime \prime} \mathrm{W}, 15^{\circ} 40^{\prime} 34^{\prime \prime} \mathrm{S}$ ) about $30 \mathrm{~km}$ west of the town of Janaúba (Figure 1a). One sample was collected in June 2014, three in July 2016, and six in June 2017. The samples came from different experimental hives. In the dry season, previously to flowering of $M$. urundeuva, honey was harvested from the hives so that no honey from the rainy season remained. Honey samples were then collected soon after the blooming period of M. urundeuva, with the honey of each hive being centrifuged and stored separate from those of other hives. The site for the collection of the reference honey samples is part of a larger wellpreserved fragment of SDTF, with an area of approximately $5.9 \mathrm{~km}^{2}$, average annual rainfall of $730.46 \mathrm{~mm}$ and temperatures ranging from 19.1 to $31.6{ }^{\circ} \mathrm{C}$ (INMET 2018)

Evaluation group of honey samplesThe 180 samples that compose the evaluation group were collected at 180 apiaries among 53 municipalities within the SDTF belt. The collection of samples was made possible through the cooperation of Companhia de Desenvolvimento dos Vales do São Francisco e do Parnaíba (CODEVASF), which is a public Brazilian development company that, among other activities, provides support to beekeepers in the semi-arid region of Brazil. This cooperation aimed to establish a protected denomination of origin for the honey produced in this region. This enabled the collection of honey samples directly from the registered local apiaries within the SDTF (Figure 2). The samples were obtained between April and September 2014, and the beekeepers were instructed to collect honey under the same conditions as cited above for the reference honey samples.

\subsection{Honey analysis and identification of pollen content}

For microscopic analysis, $10 \mathrm{~g}$ of honey from each sample was acetolyzed (Erdtman 1960) following Louveaux et al. (1978). Pollen grains were examined using an Olympus BX50 light microscope and identified by comparison with reference slides from the collection of Fundação Ezequiel Dias, Belo Horizonte, Brazil, and by consulting specific literature. Pollen grains were identified as specifically as possible to type, genus, or family. Two slides were prepared from each acetolyzed honey sample and 500 pollen grains were counted in each and summed together to calculate relative frequencies expressed in percentages. Pollen types were expressed in 

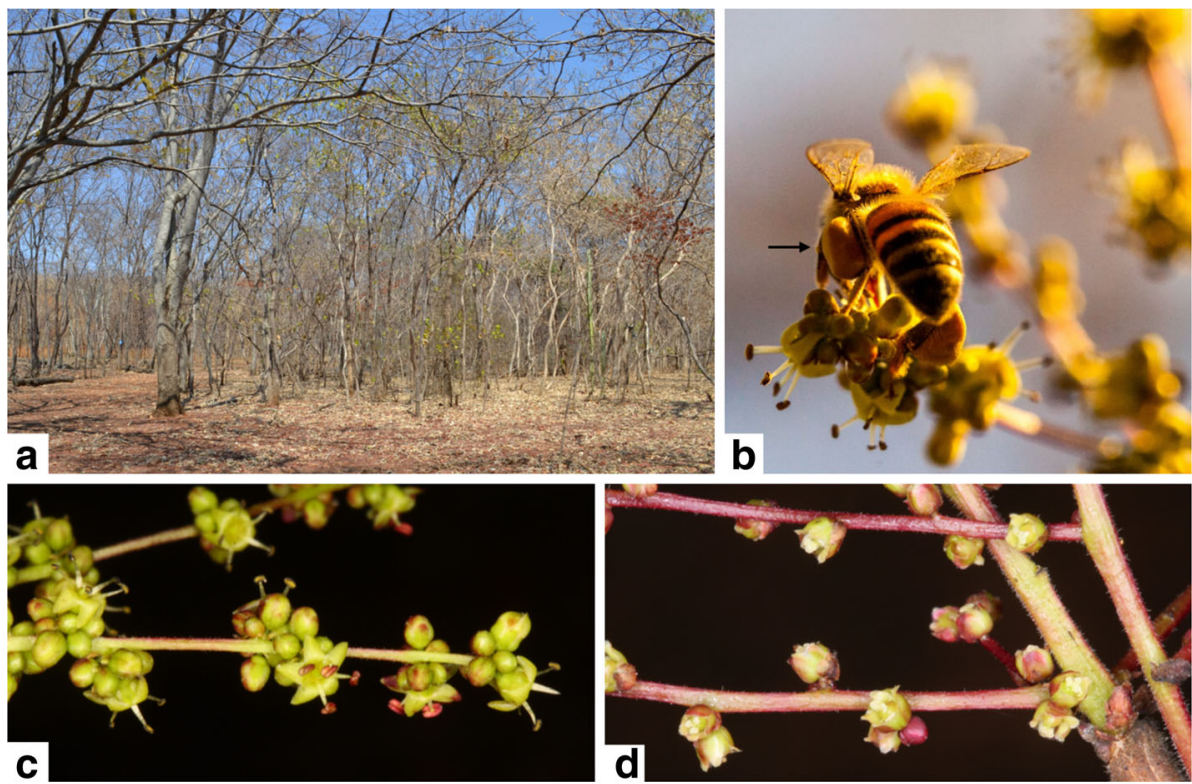

Figure 1. a Study site with typical seasonally dry tropical forest (SDTF), where reference honey samples were obtained. The trees of Myracrodruon urundeuva already shed their leaves. b Honeybee worker with full corbicula pollen load (arrow) visiting a staminate flower. c Staminate and d pistillate flowers of M. urundeuva .

standard frequency classes according to Louveaux et al. (1978) as follows: "Predominant Pollen" (PP), more than $45 \%$ of the pollen grains counted; "Secondary Pollen" (SP), 16-45\%; "Important
Minor Pollen" (IMP), 3-15\%; and "Minor Pollen" (MP), less than 3\%. Pollen grains whose frequency was $1 \%$ or less were considered as "present" (Louveaux et al. 1978), and excluded
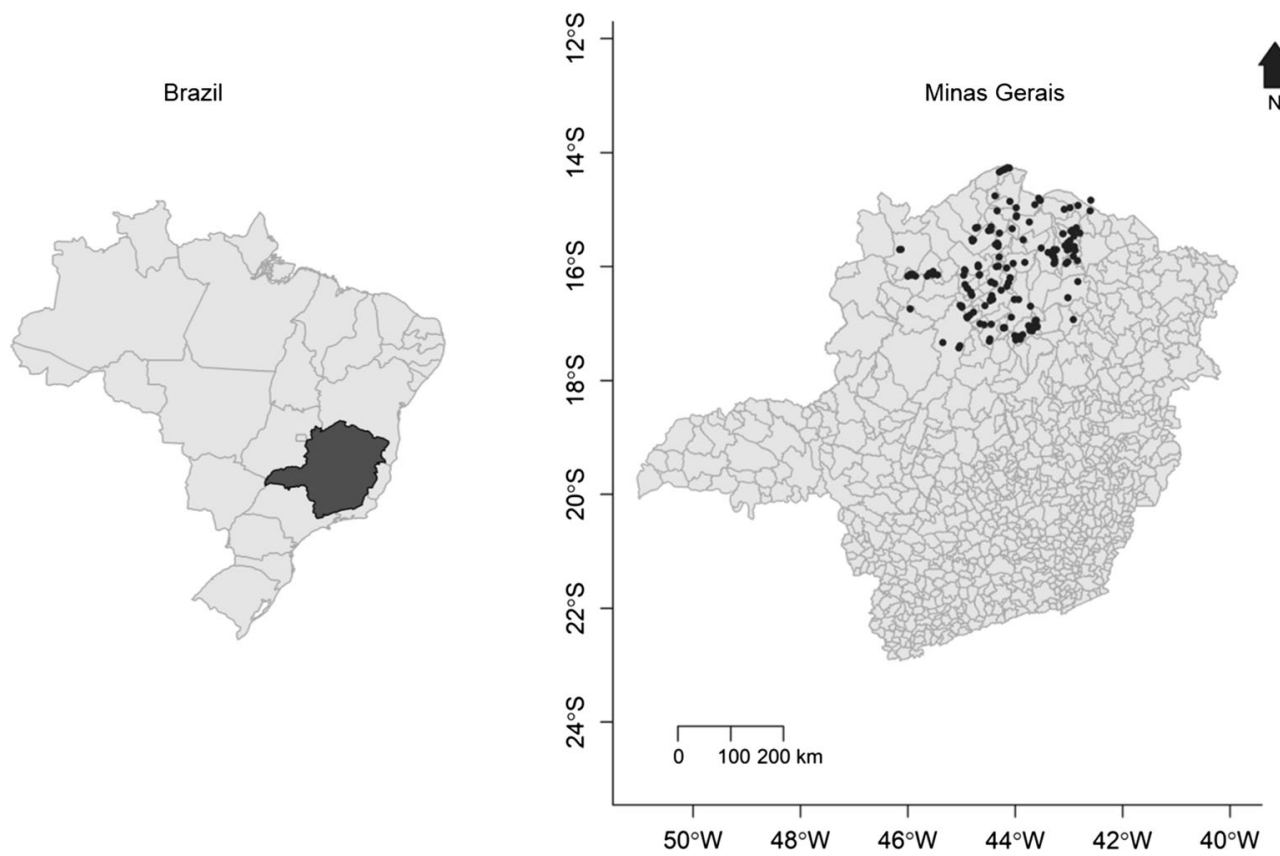

Figure 2. State of Minas Gerais, Brazil, with the locations of the analyzed honey samples $(\bullet)$. 
from statistical analysis of our quantitative dataset. The variable "number of pollen types per sample" was created and added to the data set.

\subsection{Honeybee flower visiting frequency}

The frequency of honeybee visits to staminate and pistillate flowers (Figure $1 \mathrm{~b}-\mathrm{d}$ ) was recorded in seven trees with pistillate flowers (pf) and nine trees with staminate flowers (sf). Three sf and two pf individuals were studied at the reference site and five $\mathrm{sf}$ and $\mathrm{pf}$ individuals in the municipality of Lagoa Santa (43 52' 11.0" W, 19 36' 53.7" S) between May and July 2016/2017. The number of visits was recorded by direct observation made during $5 \mathrm{~min}$ each hour of the day (Pierrot and Schlindwein 2003) on each tree. Observations of flower visits were performed using a 3-m long ladder placed in the trees. Based on the 5-min counts, we calculated the rate of flower visits for $1 \mathrm{~h}$. A total of $17 \mathrm{~h}$ of direct observation of A. mellifera visits to flowers was made.

\subsection{Statistical analysis}

First, a comprehensive exploratory analysis considering both relative frequency $(\%)$ and frequency classes (Louveaux et al. 1978) of each pollen type among samples and between reference and evaluation groups was undertaken. A descriptive analysis of pollen spectra of the reference and evaluation groups was then performed. Next, a cluster analysis was conducted using the BrayCurtis index to explore similarities among all 190 honey samples considering the relative frequencies of pollen types. The Mann-Whitney test was used to select significant variables from honey pollen spectra in the different reference and evaluation groups. Logistic regressions with the significant variables were then performed to explain the classification between groups ( $p$ value $<0.05$ )

\subsection{Receiver operating characteristic curves}

Receiver operating characteristic (ROC) curves consist of organizing classifiers and measuring the accuracy of their discrimination performance by calculating the area under the curve (AUC) (Bamber 1975; Swets 1988). This technique has been widely used in measuring the accuracy of diagnostic systems (Fawcett 2006) and to predict the distribution of species (Fielding and Bell 1997), as well as to measure the influence of climate change on the distribution of species (Giannini et al. 2012). In our study, a ROC curve was used to test the predictor variables previously selected by logistic regressions to classify honey, and to establish a cut-off value to discriminate aroeira honey samples. The experimental design with 10 reference honey samples and 180 evaluation honey samples to be classified is adequate for the performance of logistic models as well as for ROC curve analysis.

The maximum value of AUC is one, which indicates a perfect classification of samples. Therefore, we aimed to select the ROC curve with the highest AUC to establish the cut-off point for classifying the honey samples. To do this, it was necessary to analyze sensitivity and specificity values, which are parameters inherent to the ROC curve (Figure 3). Sensitivity is the true proportion of positive events in groups or, in other words, all the samples from the reference group. Specificity means the true negative proportion of samples.

All statistical analyses were done using $\mathrm{R}$ software (R Core Team 2017), with the ROC curve analysis being performed using the pROC package (Robin et al. 2011).

\section{RESULTS}

\subsection{Pollen spectra of honeys}

There were only six pollen types in the reference group of honey samples (Figure 4), with a mean percentage of Myracrodruon type of $99 \%$ \pm 2.0 (mean \pm 1 standard deviation is given throughout the text), ranging from 93 to $100 \%$ (Table I and Figure 5). Non-Myracrodruon pollen types occurred in frequencies lower than $1 \%$ ("Minor Pollen" Table I).

Forty-six pollen types were identified in the evaluation group, comprising 19 families (Table I), with a mean percentage of Myracrodruon pollen of 84\% \pm 17.7 (range 2-99\%; Table I and Figure 5). Most non-Myracrodruon pollen grains were of Eucalyptus, Mimosa, and Copaifera (Table I and Figure 4). Not to family level identified 


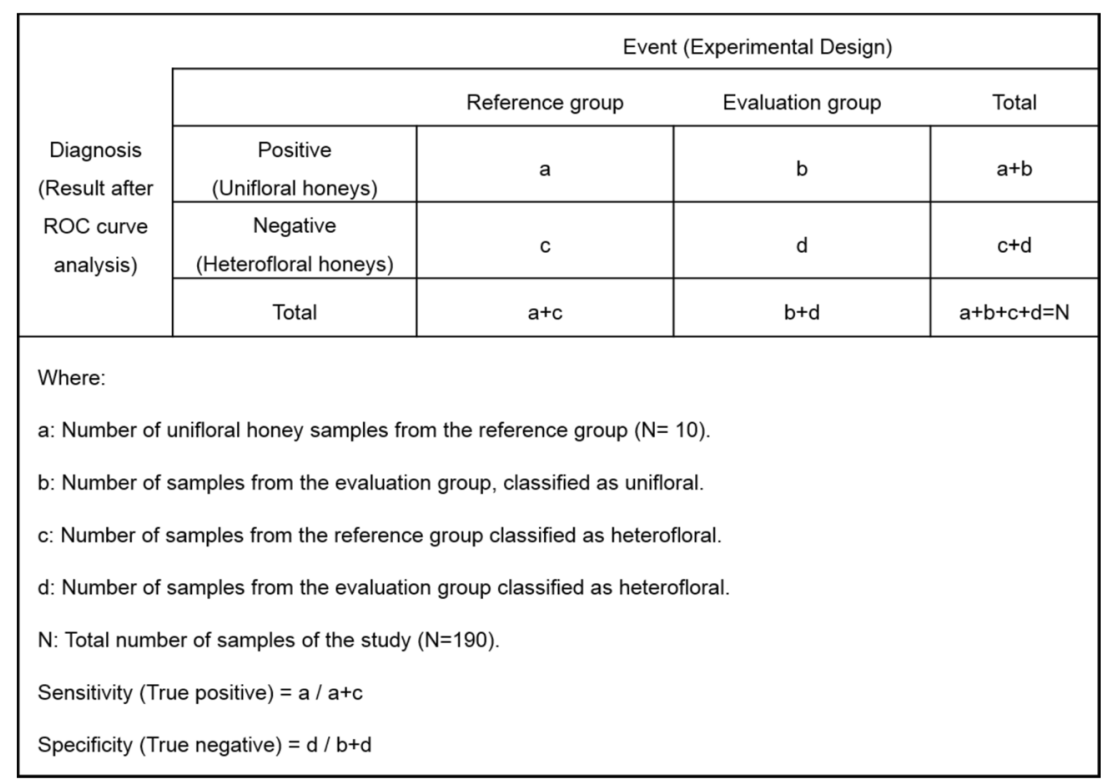

Figure 3. Matrix of classification with the definition of ROC curve parameters considering the experimental design of this honey study. Adapted from Swets (1988).

pollen types occurred in 130 samples (Table I). The median of these pollen types in a honey sample was 2 , ranging from 1 to 8 types, with median relative frequency of $2.8 \%$, ranging from 1 to $24 \%$. Pollen from Eucalyptus occurred in 50 samples, with a mean relative frequency of $4 \% \pm 18.8$ (Important Minor Pollen), while Mimosa occurred in 38 samples $(3 \% \pm 15.2)$; Copaifera had a mean frequency of $1 \% \pm 28.4$ (Minor Pollen) (Table I). Among the 46 pollen types identified, 41 occurred with frequencies $\leq$ $1 \%$, and were considered as "present" (Table I).

\subsection{Frequency of honeybee visits to pistillate and staminate flowers}

Honeybees visited on average ten times more staminate flowers $(\bar{X}=5.1 \pm 6.2)$ than pistillate flowers $(\bar{X}=0.5 \pm 3.5)$ per hour (Mann-Whitney
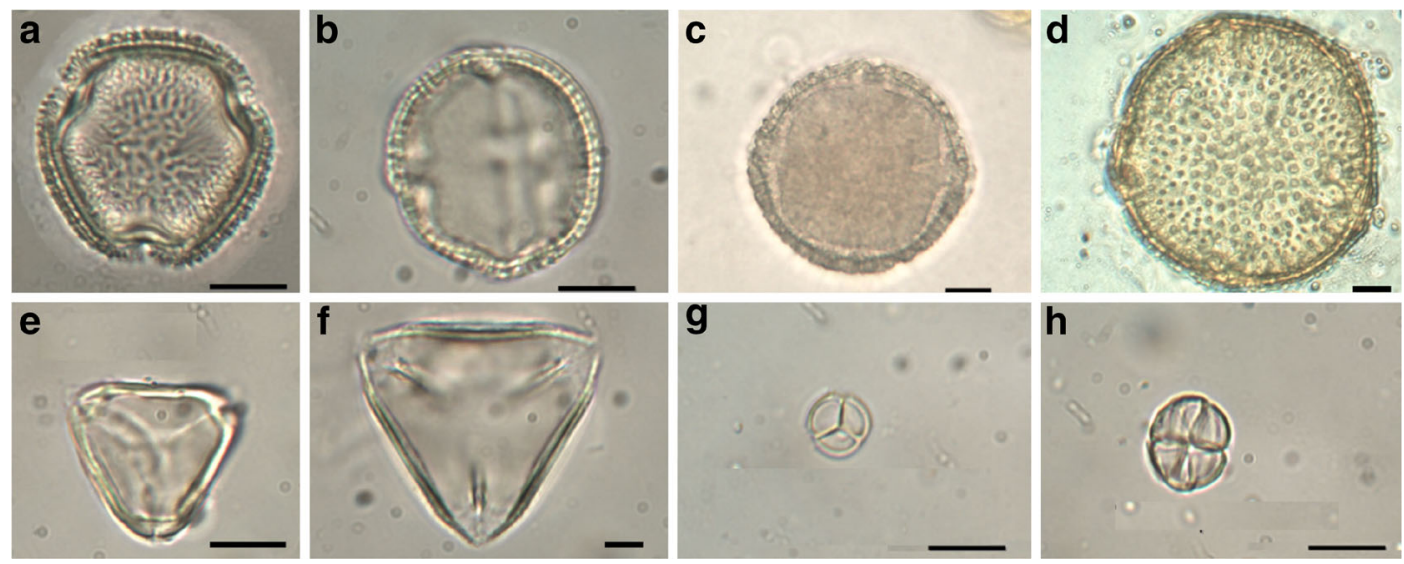

Figure 4. Main pollen types identified in honey samples analyzed in this study $(N=190)$. a, $\mathbf{b}$ Myracrodruon (Anacardiaceae). c Cordia (Boraginaceae). d Waltheria (Malvaceae). e Eucalyptus (Myrtaceae). f Copaifera (Fabaceae). g Mimosa sp1 (Fabaceae). h Mimosa sp2 (Fabaceae). Bars $=10 \mu \mathrm{m}$. 
Table I. Mean percentage or presence $(+)$ when relative frequency is less than $1 \%$, in honeys from the reference group $(N=10)$ and from evaluation group $(N=180)$

\begin{tabular}{|c|c|c|c|c|c|c|c|c|}
\hline \multirow[t]{2}{*}{ Pollen types } & \multicolumn{4}{|c|}{ Reference group } & \multicolumn{4}{|c|}{ Evaluation group } \\
\hline & $\begin{array}{l}\text { Mean } \\
\%\end{array}$ & sd & $N$ & $\begin{array}{l}\text { Frequency } \\
\text { class }\end{array}$ & $\begin{array}{l}\text { Mean } \\
\%\end{array}$ & sd & $N$ & $\begin{array}{l}\text { Frequency } \\
\text { class }\end{array}$ \\
\hline \multicolumn{9}{|l|}{ Amaranthaceae } \\
\hline Althernanthera & + & & 1 & MP & + & & 11 & MP \\
\hline Amaranthus & & & & & + & & 2 & MP \\
\hline Gomphrena & & & & & + & & 1 & MP \\
\hline \multicolumn{9}{|l|}{ Anacardiaceae } \\
\hline Anacardiaceae non-identified & + & & 2 & MP & + & & 22 & MP \\
\hline Myracrodruon & $99 \%$ & 1.97 & 10 & PP & $84 \%$ & 17.69 & 174 & PP \\
\hline Tapirira & & & & & + & & 1 & MP \\
\hline Arecaceae & & & & & + & & 2 & MP \\
\hline \multicolumn{9}{|l|}{ Asteraceae } \\
\hline Asteraceae non-identified & & & & & + & & 3 & MP \\
\hline Baccharis & & & & & + & & 6 & MP \\
\hline Chromolaema & & & & & + & & 1 & MP \\
\hline Elephantopus & & & & & + & & 1 & MP \\
\hline Vernonia & & & & & + & & 8 & MP \\
\hline \multicolumn{9}{|l|}{ Bignoniaceae } \\
\hline Jacaranda & & & & & + & & 1 & MP \\
\hline \multicolumn{9}{|l|}{ Boraginaceae } \\
\hline Cordia & + & & 1 & MP & + & & & MP \\
\hline \multicolumn{9}{|l|}{ Cecropiaceae } \\
\hline Cecropia & & & & & $1 \%$ & 4.60 & 35 & MP \\
\hline \multicolumn{9}{|l|}{ Convolvulaceae } \\
\hline Convolvulaceae non-identified & & & & & + & & 1 & MP \\
\hline Jacquemontia & & & & & + & & 1 & MP \\
\hline Merremia & & & & & + & & 17 & MP \\
\hline \multicolumn{9}{|l|}{ Euphorbiaceae } \\
\hline Croton & & & & & + & & 1 & MP \\
\hline Euphorbiaceae non-identified & & & & & + & & 3 & MP \\
\hline Sebastiania & & & & & + & & 2 & MP \\
\hline \multicolumn{9}{|l|}{ Fabaceae } \\
\hline Acacia & & & & & + & & 4 & MP \\
\hline Bauhinia & & & & & + & & 1 & MP \\
\hline Chaetocalyx & & & & & + & & 13 & MP \\
\hline Copaifera & & & & & $1 \%$ & 29.88 & 13 & MP \\
\hline Fabaceae non-identified & & & & & + & & 5 & MP \\
\hline Mimosa & & & & & $3 \%$ & 15.21 & 38 & IMP \\
\hline Senna & & & & & + & & 1 & MP \\
\hline \multicolumn{9}{|l|}{ Lamiaceae } \\
\hline Hyptis & & & & & + & & 7 & MP \\
\hline
\end{tabular}


Table I (continued)

\begin{tabular}{|c|c|c|c|c|c|c|c|c|}
\hline \multirow[t]{2}{*}{ Pollen types } & \multicolumn{4}{|c|}{ Reference group } & \multicolumn{4}{|c|}{ Evaluation group } \\
\hline & $\begin{array}{l}\text { Mean } \\
\%\end{array}$ & sd & $N$ & $\begin{array}{l}\text { Frequency } \\
\text { class }\end{array}$ & $\begin{array}{l}\text { Mean } \\
\%\end{array}$ & sd & $N$ & $\begin{array}{l}\text { Frequency } \\
\text { class }\end{array}$ \\
\hline \multicolumn{9}{|l|}{ Malvaceae } \\
\hline Bombacopsis & & & & & + & & 1 & MP \\
\hline Bombax & & & & & + & & 2 & MP \\
\hline Malvaceae non-identified & & & & & + & & 1 & MP \\
\hline Waltheria & + & & 2 & MP & + & & 1 & MP \\
\hline Melastomataceae & & & & & + & & 1 & MP \\
\hline \multicolumn{9}{|l|}{ Myrtaceae } \\
\hline Eucalyptus & & & & & $4 \%$ & 18.85 & 50 & IMP \\
\hline Myrcia & & & & & + & & 3 & MP \\
\hline Myrtaceae non-identified & & & & & + & & 3 & MP \\
\hline Non-identified pollen types & + & & 1 & MP & $4 \%$ & 4.84 & 129 & IMP \\
\hline Nyctaginaceae & & & & & + & & 1 & MP \\
\hline Poaceae & & & & & + & & 16 & MP \\
\hline Polygalaceae & & & & & + & & 1 & MP \\
\hline \multicolumn{9}{|l|}{ Rubiaceae } \\
\hline Borreria & & & & & + & & 4 & MP \\
\hline Diodia & & & & & + & & 3 & MP \\
\hline Richardia & & & & & + & & 3 & MP \\
\hline Rubiaceae non-identified & & & & & + & & 1 & MP \\
\hline \multicolumn{9}{|l|}{ Sapindaceae } \\
\hline Serjania & & & & & + & & 2 & MP \\
\hline
\end{tabular}

$s d$ standard deviation, $P P$ Predominant Pollen (> 45\%), SP Secondary Pollen (16-45\%), IMP Important Minor Pollen (3-15\%), $M P$ Minor Pollen $(<3 \%)$

test, $W=1497.5, p$ value $<0.001$ ) (Figure 6). Both staminate and pistillate flowers produced small volumes of nectar $(<0.8 \mu \mathrm{L}, \bar{X}=0.4 \pm$ $0.12, N=42)$ during the entire flower lifespan. Besides nectar, honeybees intensively collected pollen in the staminate flowers. The rate of honey bee visits to staminate flowers was high throughout the day while visits to pistillate flowers occurred primarily in the afternoon.

\subsection{Statistical analysis}

\subsubsection{Similarity among samples}

Cluster analysis of all 190 honey samples (Figure 7) revealed a well-delimited group with a low number of pollen types and a high percentage of Myracrodruon pollen. Furthermore, as the percentage of Myracrodruon pollen decreased, the number of pollen types in the honey samples increased, forming other groups of samples, such as one characterized by the presence of Mimosa and another group characterized by the presence of Eucalyptus pollen.

\subsubsection{Selection of variables and logistic regressions}

The selection of variables for logistic regression by Mann-Whitney test revealed that only five differed between the reference and the evaluation groups: Cordia, Eucalyptus, Mimosa, and Myracrodruon pollen types, and the number of pollen types (Table II). 


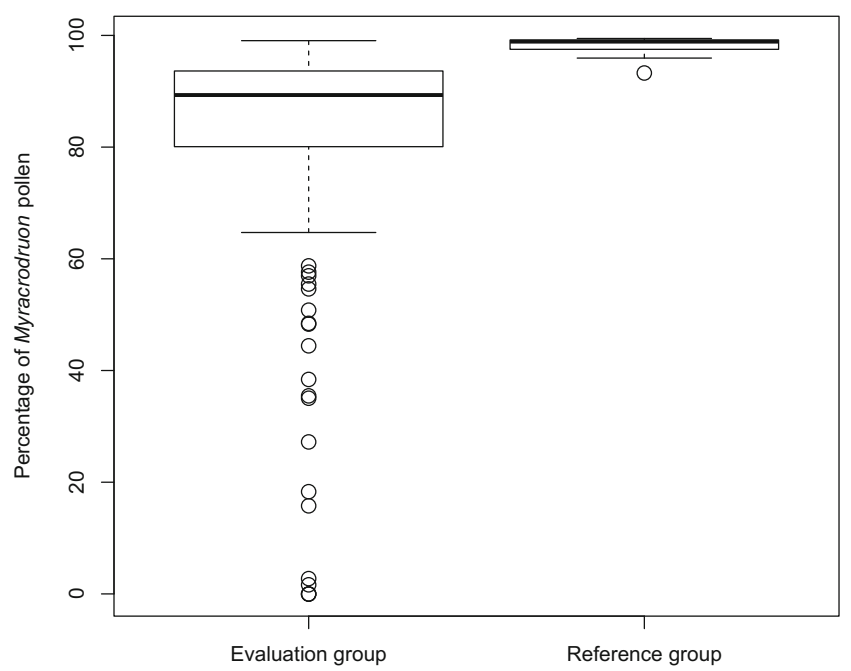

Figure 5. Relative frequency (\%) of Myracrodruon pollen in honey samples of the evaluation group $(N=180)$ and the reference group $(N=10)$.

We tested several logistic regressions with all possible combinations of the significant variables, including interactions, and only these two significant regressions were obtained: (1) percentage of Myracrodruon pollen and (2) number of pollen types in the sample (Table III).
Interpreting the odds ratio of each regression found that for every percent of increase in the relative frequency of Myracrodruon pollen in a sample, there was a twofold increase in the chance of it belonging to the reference group. In contrast, for each new pollen type identified in a honey

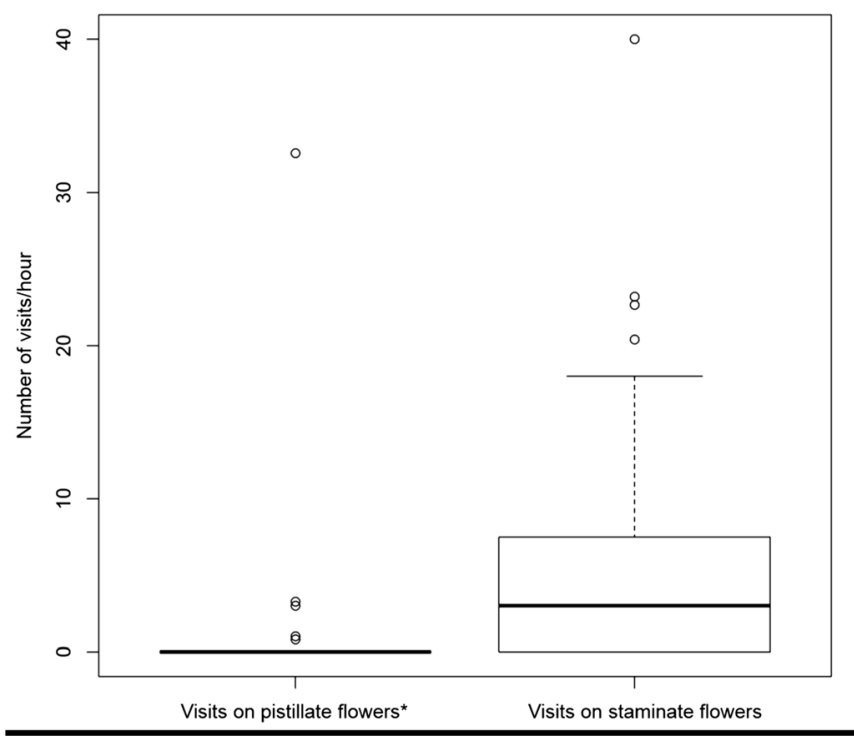

Figure 6. Number of Apis mellifera visits on pistillate and staminate flowers of Myracrodruon urundeuva per hour $(N=16$ trees, being seven with pistillate flowers and nine with staminate flowers). * Significantly different from staminate flowers (Mann-Whitney test, $p$ value $<0.001$ ). 

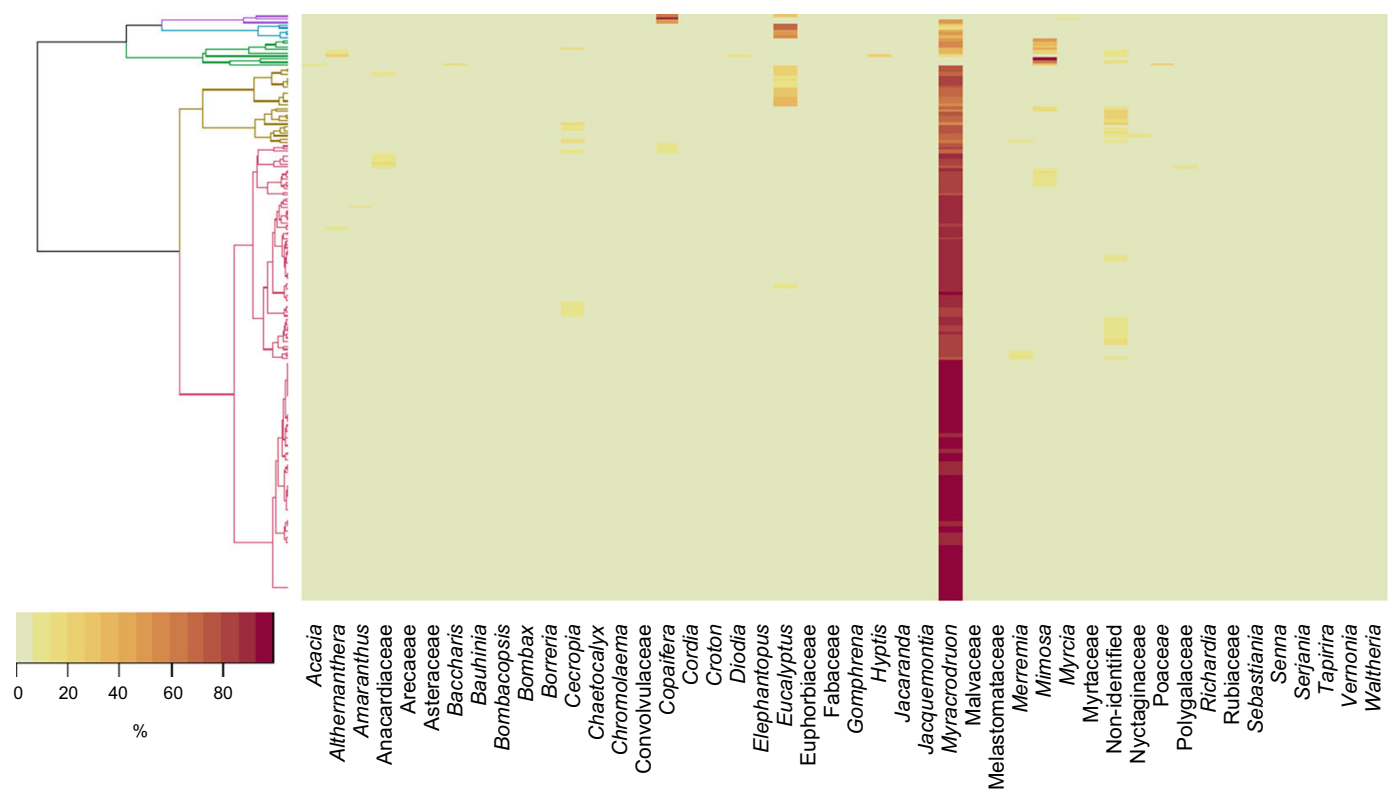

Figure 7. Dendrogram representing hierarchical clustering analysis (Bray-Curtis index) of honey samples $(N=190)$ using the relative frequency of pollen types. The heat map representation shows the percentage of each pollen type (columns) on each honey sample (rows).

sample with a relative frequency $\geq 1 \%$, the chance of the sample belonging to the reference group decreased by a multiple of approximately five (Table III and Figure 8a, b).

\subsubsection{Receiver operating characteristic curves}

AROCcurvewasconstructedforeachofthetwo significative regressions to compare their area under the curve (AUC) (Figure 8c). A higher AUC (0.945) was obtained for the first regression (\% of Myracrodruon pollen). Thus, the percentage of
Myracrodruon pollen was considered the best predictor for classifying honey samples as of the reference or evaluation group.

When using the ROC curve to establish the cut-off point for Myracrodruon pollen between the reference and the evaluation group, it was necessary to be certain that the classification of the reference group samples was fully correct. In other words, none of the reference honey samples could be classified as negative (i.e., non-aroeira honey), and that the sensitivity value must equal one. In the

Table II. Results of Mann-Whitney tests between reference $(N=10)$ and evaluation groups $(N=180)$ for significant variables of the pollen spectra of honey samples

\begin{tabular}{|c|c|c|c|c|c|}
\hline \multirow[t]{2}{*}{ Variables } & \multicolumn{2}{|c|}{ Reference group } & \multicolumn{2}{|c|}{ Evaluation group } & \multirow[t]{2}{*}{$p$ value } \\
\hline & Mean $(\%)$ & $\mathrm{se}^{\mathrm{a}}$ & Mean $(\%)$ & se & \\
\hline Cordia & 0.22 & 0.22 & 0.00 & 0.00 & $<0.001$ \\
\hline Eucalyptus & 0.00 & 0.00 & 4.07 & 0.88 & 0.06 \\
\hline Mimosa & 0.00 & 0.00 & 3.03 & 0.82 & 0.09 \\
\hline Myracrodruon type & 98.00 & 0.62 & 82.00 & 1.53 & $<0.001$ \\
\hline Number of pollen types & 1.60 & 0.27 & 3.37 & 0.12 & $<0.001$ \\
\hline
\end{tabular}

se standard error 
Table III. Results of the significative logistic regressions for classifying honey samples between reference $(N=10)$ and evaluation $(N=180)$ groups

\begin{tabular}{lccccc}
\hline Regressions & Coefficients & se & $Z$ value & Odds ratio & $p$ value \\
\hline \% of Myracrodruon pollen & 0.74 & 0.22 & -3.37 & 2.09 & $<0.001$ \\
Number of pollen types & -1.71 & 0.49 & -3.52 & 0.18 & $<0.001$ \\
\hline
\end{tabular}

se standard error

present study, when the sensitivity was one, the specificity value was 0.71 and the corresponding percentage of Myracrodruon pollen was equal to $93.2 \%$ (Figure 8d). Applying this cut-off value to the evaluation group, $52(30 \%)$ of the 180 honey samples were considered pure aroeira honey (Table IV).

\section{a}

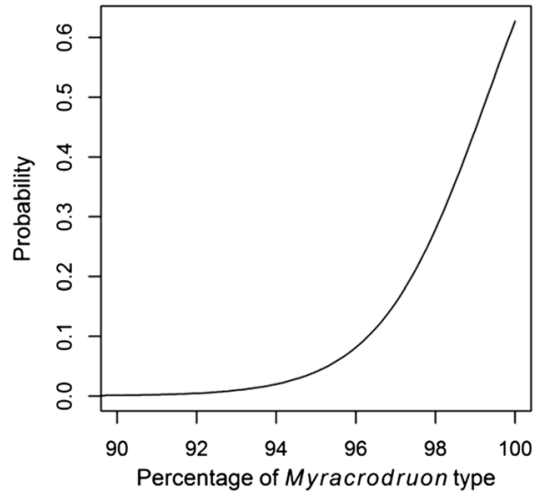

C

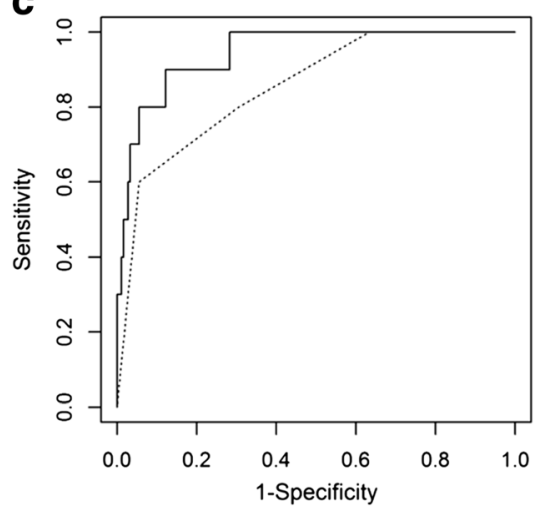

\section{DISCUSSION}

Results of the present study show that the pollen spectra of honey collected in the seasonally dry tropical forest belt of Brazil during the flowering period of Myracrodruon urundeuva can be used for indicating its botanical origin. According to

\section{b}

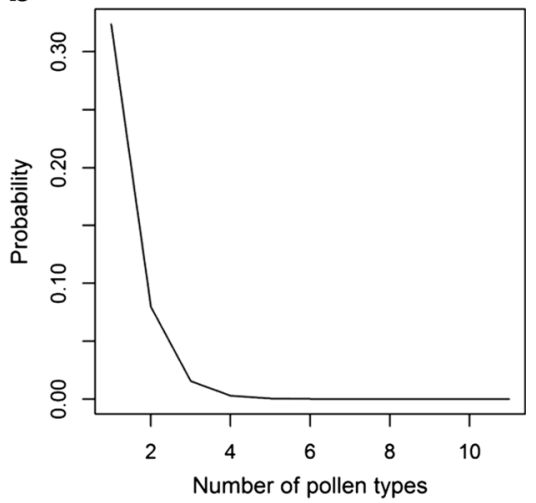

d

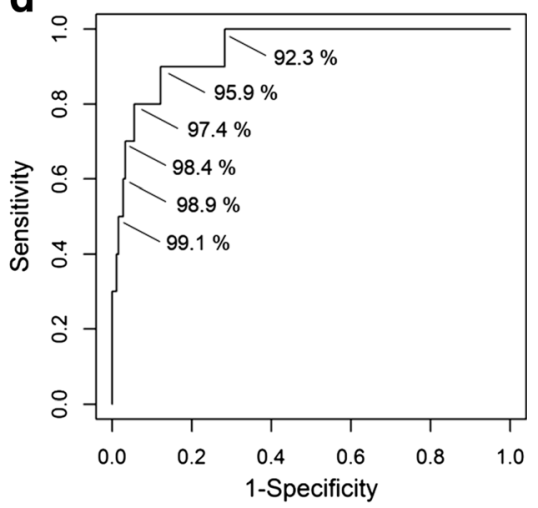

Figure 8. ROC curve plots. a Probability and the corresponding percentage of Myracrodruon pollen in a honey sample. b Probability and the corresponding number of pollen types in a honey sample. c Receiver operating characteristic (ROC) curves of the percentage of Myracrodruon pollen (bold line, AUC $=0.945$ ) and for the number of pollen types in a honey sample (dotted line, AUC $=0.853$ ). $\mathbf{d}$ ROC curve of the percentage of Myracrodruon pollen in a honey sample and the corresponding cut-off levels for several values of sensitivity and specificity. 
Table IV. Matrix of classification showing the result of honey samples classification based on a cut-off value of 93.2\% of Myracrodruon pollen in honey samples, as established by receiver operating characteristic (ROC) curve analysis

\begin{tabular}{llll}
\hline Classification result/initial groups & Reference group & Evaluation group & Total \\
\hline Unifloral honeys & 10 & 52 & 62 \\
Heterofloral honeys & 0 & 128 & 128 \\
Total & 10 & 180 & 190 \\
\hline
\end{tabular}

our data, unifloral aroeira honey should contain the following: (i) at least $93 \%$ of Myracrodruon pollen and (ii) just up to three pollen types in the frequency class "Minor Pollen" (1-3\%), using the categories of Louveaux et al. (1978).

Pollen grains of some species are overrepresented in honey showing, thus, extraordinary high percentages in pollen spectra (Louveaux et al. 1978). When compared to other established unifloral over-represented honeys, like Brassica napus (> 86\%) (Von Der Ohe et al. 2004), Eucalyptus spp. (>90\%) (Barth 1989; Bastos et al. 2003), Castanea sativa Mill. (>90\%) (Oddo et al. 2004), and Mimosa scabrella Benth. (92\%) (Azevedo et al. 2017), the percentage of Myracrodruon pollen in aroeira honey is also very high.

The uniform pollen spectra, with the extraordinary high percentage of aroeira pollen, for this unifloral honey can be explained by the striking seasonality of the synchronized blooming period of this species, when few other melliferous plants set flower in the Brazilian SDTF belt. Moreover, it reflects the importance of the species as source of pollen besides nectar for honeybees. The mass flowering trees of this dioecious species produce five times more staminate flowers than pistillate flowers (Kiill et al. 2010), and our study showed that honeybees have a strong preference for the staminate flowers (visitation rates about tenfold higher) when compared to foraging on pistillate nectar flowers. A similar strong preference of honeybees (fivefold more visits) for staminate flowers of $M$. urundeuva was also reported in the Caatinga (Kiill et al. 2010). Moreover, trees with staminate flowers are more frequent than those with pistillate flowers in M. urundeuva populations. In the present study, $60 \%$ of the trees had staminate flowers while $40 \%$ of trees had pistillate flowers, which is similar to the findings of Kiill et al. (2010), with 61 and 39\%, respectively. Furthermore, trees of M. urundeuva are highly abundant in the Brazilian SDTF (Santos et al. 2007; Caetano et al. 2008; Santos et al. 2012), which might be a consequence of an allelopathic effect caused by secondary compounds produced by their leaves (Moreira et al. 2007). All these factors together favor massive entry of the small pollen grains into the honey.

Originating from a dioecious tree species in near-natural environments, aroeira honey is exceptional among honeys. Dioecy is found in 5 to $6 \%$ of angiosperm species (Renner 2014) and it is expected that flowers of dioecious plants attract primarily nectar feeders to guarantee pollination (Richards 1997). Highly eusocial bees demonstrate the ability to discriminate between flowers with the more rewarding morph in tropical dioecious species (Renner and Feil 1993). This may have the result that plants with staminate flowers can temporarily be the main pollen source, for example to honeybees in flowers of Spondias mombin L. (Anacardiaceae), Pouteria stipitata Cronquist (Sapotaceae), and species of Zanthoxyllum (Rutaceae) (Roubik 1989), but that pistillate flowers are barely visited and, thus, pollinated by these bees (Renner and Feil 1993). The strong honeybee preference for staminate flowers of M. urundeuva found in our study corroborates with the above mentioned examples.

The floral display of male plants in M. urundeuva is increased in number of flowers and inflorescences in comparison to female plants, similar to other dioecious trees. In general, these species invest more in pollen production when compared to hermaphroditic species (Bawa 1980). This is also true for other dioecious neotropical Anacardiaceae such as Astronium fraxinifolium Schott (Cornacini et al. 2017), Schinopsis brasiliensis Engl. (Kiill et al. 
2010), Schinus terebinthifolia Raddi (Lenzi and Orth 2004), and Tapirira guianensis Aubl. (Lenza and Oliveira 2005), which are strongly attractive to highly eusocial bees. Pollen of these plants is most likely over-represented in honeys like those of Myracrodruon in aroeira honey. Pollen of most dioecious species, however, is under-represented in honey samples because pistillate and staminate flowers attract pollinators mainly by nectar (Louveaux et al. 1978).

The presence of Eucalyptus pollen in the honey samples was negatively correlated with the presence of aroeira pollen, indicating that, when present, honeybees also use the widely known highly melliferous Eucalyptus flowers (Simeão et al. 2015), when its flowering overlaps with that of M. urundeuva. Eucalyptus plantations in the semi-arid region of northeast Brazil are usually in irrigated areas due to limited rainfall concentrated over short periods of the year, which causes lower yields (Azar and Larson 2000).

Mimosa -type pollen (minor pollen) was present only in the pollen spectra of the evaluation group honeys, although numerous species from this and other genera of Mimosoideae are native and a common source of nectar and pollen for bees in SDTF (Simon and Proença 2000; Santos et al. 2012, 2007, 2006). Most of these species, however, flower in the rainy season and are important constituents of heterofloral honeys collected outside the dry season in this region (Bastos et al. 2003; Novais et al. 2009; Silva and Santos 2014). Samples with any percentage of Mimosa -type pollen had decreased percentages of Myracrodruon pollen (Spearman's correlation $r=-0.37, p$ value $=0.0$ ). We suppose that mixtures of dry and rainy season honeys contain more Mimosa-type pollen. To obtain rather pure aroeira honey, beekeepers, therefore, should collect honey immediately after the blooming period of M. urundeuva .

The establishment of the cut-off value or threshold on pollen relative frequency in unifloral honeys can be assessed by diagnostic system techniques. They provide a discrimination of two groups or alternatives (e.g., being a unifloral honey) by using a specific threshold or cut-off value (Swets 1988). The success of these applications relies on the accuracy of the models given by the ROC curve analysis (Liu et al. 2011). The ROC curve analysis proved to be a suitable tool for determining a cutoff value for classifying unifloral honey. To our knowledge, this is the first use of this approach in melissopalynology, and we recommend its application for the evaluation of other kinds of unifloral honeys. However, to do this, it is necessary to define a standard reference group of monitored honey samples. In addition, other honey predictors, not only related to the pollen spectra of honey, may also be used in the ROC curve analysis, such as variables from physicochemical honey analysis.

Unifloral honeys produced from natural or nearnatural plant cover are rare in the world and include manuka honey derived from Leptospermum scoparium J.R. Forst. \& G. Forst. and L. ericoides A. Rich. (Myrtaceae) in New Zealand (Moar 1985), Euphorbia honey (Euphorbiaceae) in Marroco (Terrab et al. 2014), Humboldt's willow honey (Salix humboldtiana Willd., Salicaceae) in Argentina (Fagúndez 2016), and bracatinga honey (Mimosa scabrella, Fabaceae) in southern Brazil (Azevedo et al. 2017), among which aroeira honey soon may be added.

We conclude that aroeira honey shows a uniform pollen spectra with an extraordinary high percentage of pollen from this plant that allows the palynological definition of this honey as unifloral. This high relative amount of aroeira pollen in the honey is the result of synchronized mass flowering of this dioecious species in the dry season, when blooming of other bee plants is scarce in the Brazilian SDTF belt, as well as its high abundance in natural and semi-natural SDTF vegetation, and the strong preference of honeybees for trees with pollen- and nectar-producing staminate flowers over those with only nectarproducing pistillate flowers. The ROC curve analysis, applied to melissopalynology for the first time, proved to be an efficient tool for defining this unifloral honey. The presented results are a basic contribution for the control of origin and quality standard, which, together with the physicochemical characteristics, are important in establishing the protected denomination of origin (PDO) for aroeira honey. Considering pollination biology, it would be interesting to evaluate the pollination effectiveness of honeybees in comparison to native stingless bees, which are also common native flower visitors of $M$. urundeuva . 


\section{ACKNOWLEDGEMENTS}

We especially acknowledge Sr. José de Calazans, who provided the incentive to study unifloral aroeira honey. He helped in providing reference honey samples from experimental bee hives and with logistics of field work. We thank two anonymous reviewers for their constructive comments, which improved the manuscript. We thank Companhia de Desenvolvimento dos Vales do São Francisco e do Parnaíba (CODEVASF) for financial support, and numerous associated beekeepers for their aid in obtaining the honey sample, and the Banco do Nordeste do Brasil S/A and Fundação de Amparo à Pesquisa do Estado de Minas Gerais (FAPEMIG) for financial support. We also thank Milton Silveira for support in field work and discussion, Cláudia Simeão, Rânia Santana, Lívia Gardoni, and Guilherme Rodrigues, who helped to mount and analyze pollen slides; André Calaça da Costa, who assisted with the statistical analysis; and Cláudia Simeão, Cynthia Luz, and Maria Beatriz for their comments on an earlier version of the manuscript. PC received a scholarship from FAPEMIG and CS from CNPq.

\section{AUTHOR CONTRIBUTIONS}

EMAFB conceived the research. PC performed the analysis. CS and EMAFB contributed to the experimental design. EMAFB contributed to the pollen identification. PC, CS, and EMAFB interpreted results. PC and CS wrote the paper. All authors read and approved the final manuscript.

\section{FUNDING INFORMATION}

This research had financial support from Banco do Nordeste do Brasil, Fundação de Amparo à Pesquisa do Estado de Minas Gerais, and Companhia de Desenvolvimento dos Vales do São Francisco e do Parnaíba.

\section{COMPLIANCE WITH ETHICAL STANDARDS}

Conflict of interest The authors declare that they have no conflict of interest.

Discrimination du miel unifloral à partir d'un arbre diö̈que à floraison massive de forêt sèche tropicale du
Brésil à travers les specters de pollen: conséquences de la préférence des abeilles pour les fleurs mâles

Myracrodruon urundeuva / courbe-ROC / mélissopalynologie / Apis mellifera

Unterscheidung von unifloralen Honigen eines diözischen massenblütigen Baumes aus dem brasilianischen wechselfeuchten Tropenwald anhand des Pollenspektrums: Konsequenzen auf die Honigbienenpräferenz für männliche Blütenstände

Myracrodruon urundeuva / ROC-Kurve / melissopalynologie / Apis mellifera

\section{REFERENCES}

Andrade-Lima, D. (1981) The caatinga dominium. Braz. J. Bot. 4, 149-163

Anklam, E. (1998) A review of the analytical methods to determine the geographical and botanical origin of honey. Food Chem. 63, 549-562

Azar, C., Larson, E.D. (2000) Bioenergy and land-use competition in Northeast Brazil. Energy Sustain. Dev. 4, 64-71

Azevedo, M.S., Valentim-Neto, P.A., Seraglio, S.K.T., Luz, C.F.P., Arisi, A.C.M., Costa, A.C.O. (2017) Proteome comparison for discrimination between honeydew and floral honeys from botanical species Mimosa scabrella Bentham by principal component analysis. J. Sci. Food Agric. 97, 4515-4519

Bamber, D. (1975) The area above the ordinal dominance graph and the area below the receiver operating characteristic graph. J. Math. Psychol. 12, 387-415

Barth, O.M. (1989) O pólen no mel brasileiro. Instituto Oswaldo Cruz, Rio de Janeiro

Barth, O.M. (2004) Melissopalynology in Brazil: a review of pollen analysis of honeys, propolis and pollen loads of bees. Sci. Agric. 61, 342-350

Bastos, E.M.A.F., Calaça, P.S.S.T., Simeão, C.M.G., Cunha, M.R.R. (2016) Characterization of the honey from Myracrodruon urundeuva (Anacardiaceae-Aroeira) in the Dry Forest of northern of Minas Gerais/Brazil. Adv. Agric Sci. 4, 64-71

Bastos, E., Silveira, V., Soares, A. (2003) Pollen spectrum of honey produced in Cerrado areas of Minas Gerais State (Brazil). Braz. J. Biol. 63, 599-615

Bawa, K.S. (1980) Evolution of dioecy in flowering plants. Annu. Rev. Ecol. Syst. 11, 15-39

Brandão, M. (1994) Área Mineira do Polígono das Secas/ cobertura vegetal. Inf. Agropecu. 17, 5-9

Bryant, V.M. Jr., Jones, G.D. (2001) The r-values of honey: Pollen coefficients. Palynology 25, 11-28 
Caetano, S., Prado, D., Pennington, R., Beck, S., OliveiraFilho, A., Spichiger, R., Naciri, Y. (2008) The history of seasonally dry tropical forests in eastern South America: inferences from the genetic structure of the tree Astronium urundeuva (Anacardiaceae). Mol. Ecol. 17, 3147-3159

Calvo-Rodriguez, S., Espírito-Santo, M.M., Nunes, Y.R.F., Calvo-Alvarado, J. (2017) Tree diameter growth for three successional stages of Tropical Dry Forest in Minas Gerais, Brazil. Rev. Florest. Mesoam. Kurú 14, 24-32

Consonni, R., Cagliani, L.R. (2015) Recent developments in honey characterization. RSC Adv. 5, 59696-59714

Cornacini, M.R., Silva, J.R., Luz, K.C., Cambuim, J., Santos, W., Moraes, M., Aguiar, A.V. (2017) Selective thinning in provenance and progeny test of Astronium fraxinifolium Schott based on genetic variability. Sci. Forums 45, 581-591

Erdtman, G. (1960) The acetolysis method - a revised description. Sven. Bot. Tidskr. 54, 516-564

Faegri, K., Kaland, P.E., Krzywinski, K. (1989) Textbook of pollen analysis. John Wiley \& Sons, New York

Fagúndez, G. (2016) Botanical and geographical characterisation of honeys in Diamante, Entre Ríos, Argentina. Palynology 40, 308-321

Fawcett, T. (2006) An introduction to ROC analysis. Pattern Recogn. Lett. 27, 861-874. https://doi. org/10.1016/j.patrec.2005.10.010

Fielding, A.H., Bell, J.F. (1997) A review of methods for the assessment of prediction errors in conservation presence/absence models. Environ. Conserv. 24, 3849

Giannini, T.C., Acosta, A.L., Garófalo, C.A., Saraiva, A.M., Alves-dos-Santos, I., Imperatriz-Fonseca, V.L. (2012) Pollination services at risk: bee habitats will decrease owing to climate change in Brazil. Ecol. Model. 244, 127-131

Goplen, B. (1980) Sweetclover production and agronomy. Can. Vet. J. 21,149

INMET (2018) Rede de Estações Climatológicas. Instituto Nacional de Metereologia. http://www.inmet.gov. br/portal/index.php?r=bdmep/bdmep. Accessed 10 Jan 2018

Kadri, S.M., Zaluski, R., Lima, G.P.P., Mazzafera, P., Oliveira Orsi, R. (2016) Characterization of Coffea arabica monofloral honey from Espírito Santo, Brazil. Food Chem. 203, 252-257

Kiill, L.H.P., Martins, C., Silva, P. (2010) Biologia reprodutiva de duas espécies de Anacardiaceae da caatinga ameaçadas de extinção. In: Moura, A.N., Araújo, E.L., Albuquerque, U.P. (eds) Biodiversidade, potencial econômico e processos ecofisiológicos em ecossistemas nordestinos. Embrapa Semiárido, Bauru, pp 305-332

Lenza, E., Oliveira, P.E. (2005) Biologia reprodutiva de Tapirira guianensis Aubl. (Anacardiaceae), uma espécie dióica em mata de galeria do Triângulo Mineiro, Brasil. Rev. Bras. Bot. 28, 179-190.
Lenzi, M., Orth, A.I. (2004) Fenologia reprodutiva, morfologia e biologia floral de Schinus terebinthifolius Raddi (Anacardiaceae), em restinga da Ilha de Santa Catarina, Brasil. Biotemas 17, 67-89

Liu, C., White, M., Newell, G. (2011) Measuring and comparing the accuracy of species distribution models with presence-absence data. Ecography 34, 232-243

Louveaux, J., Maurizio, A., Vorwohl, G. (1978) Methods of melissopalynology. Bee World 59, 139-157

Louveaux, J., Vergeron, Ph. (1964) Étude du spectre pollinique de quelques miels espagnols. Ann. Abeille 7, 329-347

Makhloufi, C., Kerkvliet, J., Schweitzer, P. (2015) Characterisation of some monofloral Algerian honeys by pollen analysis. Grana 54, 156-166

Marquele-Oliveira, F., Carrão, D.B., Souza, R.O., Baptista, N.U., Nascimento, A.P., Torres, E.C., Moreno, G.P., Buszinski, A.F.M., Miguel, F.G., Cuba, G.L., Reis, T.F., Lambertucci, J., Redher, C., Berretta, A.A. (2017) Fundamentals of Brazilian Honey Analysis: An Overview. In: Toledo, V.A.A. (ed) Honey Analysis. InTech, pp 139-170. https://doi.org/10.5772/67279

Maurizio, A., Hodges, F. (1951) Pollen analysis of honey. Bee World 32, 1-5

Moar, N. (1985) Pollen analysis of New Zealand honey. N. Z. J. Agric. Res. 28, 39-70

Monteiro, J.M., Araújo, E.L., Amorim, E.L.C., Albuquerque, U.P. (2012) Valuation of the Aroeira (Myracrodruon urundeuva Allemao): perspectives on conservation. Acta Bot. Bras. 26, 125-132

Moreira, R.G., Fernandes, G.W., Almada, E.D., Santos, J.C. (2007) Galling insects as bioindicators of land restoration in an area of Brazilian Atlantic Forest. Lundiana 8, 107-112

Nedic, N., Macukanovic-Jocic, M., Rancic, D., Rørslett, B., Sostaric, I., Stevanovic, Z.D., Mladenovic, M. (2013) Melliferous potential of Brassica napus L. subsp. napus (Cruciferae). Arthropod Plant Interact. 7, 323333

Novais, J.S., Lima, L.C.L., Santos, F.A.R. (2009) Botanical affinity of pollen harvested by Apis mellifera L. in a semi-arid area from Bahia, Brazil. Grana 48, 224-234

Oddo, L.P., Piazza, M., Sabatini, A., Accorti, M. (1995) Characterization of unifloral honeys. Apidologie 26, 453-465

Oddo, L.P., Piro, R., Bruneau, É., Guyot-Declerck, C., Ivanov, T., Piskulová, J., Flamini, C., Lheritier, J., Morlot, M., Russmann, H. et al (2004) Main European unifloral honeys: descriptive sheets. Apidologie 35, S38-S81

Pennington, R.T., Lavin, M., Oliveira-Filho, A. (2009) Woody plant diversity, evolution, and ecology in the tropics: perspectives from seasonally dry tropical forests. Annu. Rev. Ecol. Syst. 40, 437-457

Pierrot, L.M., Schlindwein, C. (2003) Variation in daily flight activity and foraging patterns in colonies of uruçu- Melipona scutellaris Latreille (Apidae, Meliponini). Rev Bras. Zool. 20, 565-571 
Prado, D.E., Gibbs, P.E. (1993) Patterns of species distributions in the dry seasonal forests of South America. Ann. Mo. Bot. Gard. 80, 902-927

Queiroz, C.R.A.A., Morais, S.A.L., Nascimento, E.A. (2002) Characterization of aroeira-preta (Myracrodruon urundeuva) wood tannins. Rev. Árvore 26, 493-497.

R Core Team (2017) R: A language and environment for statistical computing. R Foundation for Statistical Computing, Vienna

Renner, S.S. (2014) The relative and absolute frequencies of angiosperm sexual systems: dioecy, monoecy, gynodioecy, and an updated online database. Am. J. Bot. 101 , 1588-1596

Renner, S.S., Feil, J.P. (1993) Pollinators of tropical dioecious angiosperms. Am. J. Bot. 80, 1100-1107.

Richards, A.J. (1997) Plant breeding systems. Garland Science, London

Robin, X., Turck, N., Hainard, A., et al. (2011) pROC: an open-source package for $\mathrm{R}$ and $\mathrm{S}+$ to analyze and compare ROC curves. BMC Bioinformatics 12, 77. https://doi.org/10.1186/1471-2105-12-77

Roubik, D.W. (1989) Ecology and natural history of tropical bees. Cambridge University Press, Cambridge

Santin, D.A., Leitão, H.F. (1991) Restabelecimento e revisão taxonômica do gênero Myracrodruon Freire Allemao (Anacardiaceae). Rev. Bras. Bot. 14, 133145

Santos, F.A.R., Oliveira, J., Oliveira, P., Leite, K., Carneiro, C. (2006) Plantas do semi-árido importantes para as abelhas. In: Santos, F.A.R. (ed) Apium Plantae. Associação Plantas do Nordeste, Recife, pp 61-86

Santos, R.M., Oliveira-Filho, A.T., Eisenlohr, P.V., Queiroz, L.P., Cardoso, D.B., Rodal, M.J. (2012) Identity and relationships of the Arboreal Caatinga among other floristic units of seasonally dry tropical forests (SDTFs) of north-eastern and Central Brazil. Ecol. Evol. 2 , 409-428
Santos, R.M., Vieira, F.A., Fagundes, M., Nunes, Y.R.F., Gusmão, E. (2007) Floristic richness and similarity of eight forest remnants in the north of Minas Gerais state, Brazil. Rev. Árvore 31, 135-144.

Silva, A.P.C., Santos, F.A.R. (2014) Pollen diversity in honey from Sergipe, Brazil. Grana 53, 159-170

Simeão, C., Silveira, F., Sampaio, I., Bastos, E. (2015) Pollen analysis of honey and pollen collected by Apis mellifera Linnaeus, 1758 (Hymenoptera, Apidae), in a mixed environment of Eucalyptus plantation and native Cerrado in Southeastern Brazil. Braz. J. Biol. 75, 821-829.

Simon, M., Proença, C. (2000) Phytogeographic patterns of Mimosa (Mimosoideae, Leguminosae) in the Cerrado biome of Brazil: an indicator genus of high-altitude centers of endemism? Biol. Conserv. 96, 279-296

Swets, J.A. (1988) Measuring the accuracy of diagnostic systems. Science 240, 1285-1293

Terrab, A., Marconi, A., Bettar, I., Msanda, F., Díez, M.J. (2014) Palynological characterisation of Euphorbia honeys from Morocco. Palynology 38, 138-146

Tette, P.A., Guidi, L.R., Bastos, E.M., Fernandes, C., Gloria, M.B.A. (2017) Synephrine-A potential biomarker for orange honey authenticity. Food Chem. 229, 527533

Todd, F.E., Vansell, G.H. (1942) Pollen grains in nectar and honey. J. Econ. Entomol. 35, 728-731

Viana, G., Matos, F., Bandeira, M., Rao, V. (1995) Aroeirado-sertão (Myracrodruon urundeuva Fr. All.): estudo botânico, farmacognóstico, químico e farmacológico. UFC, Fortaleza

Von Der Ohe, W., Persano Oddo, L., Piana, M.L., Morlot, M., Martin, P. (2004) Harmonized methods of melissopalynology. Apidologie 35, S18-S25

Westerkamp, C., Claßen-Bockhoff, R. (2007) Bilabiate flowers: the ultimate response to bees? Ann. Bot. 100, 361-374 